\title{
Chapter 5 \\ Tsunami Damage to Farming Operations and the New Generation of Farmers and Farm Management
}

\author{
Yukio Shibuya, Takahiro Yamada, Nyamkhuu Batdelger, \\ Puangkaew Lurhathaiopath, Gentaro Suzumura, and Toshiyuki Monma
}

\begin{abstract}
In this chapter, we show a survey of farmers' inclination to resume farming and some actions of agricultural recovery that we carried out for the farmers where the city of Soma suffered from the tsunami disaster. Three agricultural corporations were established at the rice paddy area, and one agricultural corporation was established at the strawberry production area to resume farming in the tsunami disaster area. We show process of the establishment of these agricultural corporations and show the actual situation of the activity and a future problem.
\end{abstract}

Keywords Resume farming $\bullet$ Regional agricultural recovery associations $\bullet$ Tsunami damage $\bullet$ Agricultural corporation

\footnotetext{
Y. Shibuya $(\bowtie) \bullet$ T. Yamada $\bullet$ G. Suzumura $\bullet$ T. Monma Department of International Biobusiness Studies, Tokyo University of Agriculture, 1-1-1 Sakuragaoka, Setagaya-ku, Tokyo 156-8502, Japan e-mail: y3shibuy@nodai.ac.jp

N. Batdelger

Business Management, National University of Mongolia, Sukhbaatar Duureg, Ulaanbaatar 210646, Mongolia

P. Lurhathaiopath

Faculty of Life and Environmental Sciences, Tsukuba University,

1-1-1 Tennodai, Tsukuba City, Ibaraki Prefecture 305-8577, Japan 


\subsection{Damage to Key Farmers' Operations, Farmers' Inclination to Resume Farming, and Factors Inhibiting Resumption of Farming}

\subsubsection{Assessment of Damage to Farming Operations, and Survey Targeting Resumption of Farming}

From June 12 to 15, and from June 24 to 29, 2011, we conducted an oral survey of 39 farming households affected by the tsunami in the city of Soma. We then conducted an aggregate analysis of 27 of these 39 households that grew rice as their main crop.

First, we investigated the proportion of paddy fields flooded by seawater and found that only $7 \%$ of the total paddy area escaped flooding entirely, while the proportion flooded by $0-20 \%$ was also low, at $4 \%$. On the other hand, $19 \%$ of the paddy area was flooded by $60-80 \%$ and $22 \%$ was flooded by $80-99 \%$, while $37 \%$ of the total area was $100 \%$ flooded. Thus, despite differences in the level of damage among the survey respondents, we found that almost all of them had suffered some form of flooding damage. Next, we investigated the damage inflicted on the four main types of farming machinery, namely tractors, rice planters, combines, and dryers. The farmers were polarized in terms of the levels of damage sustained, with $59 \%$ having suffered no damage at all to their machinery versus $30 \%$ whose machinery was totally destroyed, and the remaining $11 \%$ having suffered only partial damage.

\subsubsection{Inclination to Farm in Future and Associated Factors}

We asked the farmers about their inclination to continue farming, a key factor in considering the future of farming in the disaster zones. Five potential responses were allowed, with two of them-"Expand scale" and "Maintain current scale"based on the assumption that farming would be continued. The other three responses were "Reduce scale," "Leave farming," or "I don't know." We also asked about the farmers' inclination to continue farming before the disasters, because we needed to compare their intentions before and after. The results are shown in the Total column in Table 5.1. After the disasters, the proportion of those who answered "Expand scale" or "Maintain current scale" was reduced, whereas the proportion of those who answered "Reduce scale," "Leave farming," or "I don't know" increased. From this data we note an overall decline in farmers' inclination to farm that can be attributed to the earthquake and tsunami disaster.

Upon analyzing the factors behind the decline in inclination to farm, we discovered that those who owned 5 ha or more of land showed some increase in pessimism compared to before the disaster, although none of these farmers replied "Leave farming" or "I don't know." On the other hand, there was increased pessimism after 
Table 5.1 Changes in inclination to farm before and after the disasters

\begin{tabular}{l|l|l|l|l|l|l}
\hline & \multicolumn{2}{l|}{$\begin{array}{l}\text { All farmers } \\
n=27\end{array}$} & \multicolumn{2}{l|}{$\begin{array}{l}\text { Farmers owned } \\
5 \text { ha or more } n=11\end{array}$} & \multicolumn{2}{l}{$\begin{array}{l}\text { Farmers owned } \\
\text { less than 5 ha } n=16\end{array}$} \\
\cline { 2 - 8 } & $\begin{array}{l}\text { Before } \\
\text { disaster }\end{array}$ & $\begin{array}{l}\text { After } \\
\text { disaster }\end{array}$ & $\begin{array}{l}\text { Before } \\
\text { disaster }\end{array}$ & $\begin{array}{l}\text { After } \\
\text { disaster }\end{array}$ & $\begin{array}{l}\text { Before } \\
\text { disaster }\end{array}$ & $\begin{array}{l}\text { After } \\
\text { disaster }\end{array}$ \\
\hline Expand scale & 5 & 4 & 4 & 3 & 1 & 1 \\
\hline $\begin{array}{l}\text { Maintain current } \\
\text { scale }\end{array}$ & 20 & 11 & 7 & 5 & 13 & 6 \\
\hline Reduce scale & 2 & 6 & 0 & 3 & 2 & 3 \\
\hline Leave farming & 0 & 3 & 0 & 0 & 0 & 3 \\
\hline I don't know & 0 & 3 & 0 & 0 & 0 & 3 \\
\hline
\end{tabular}

Source: Cited from Shibuya et al. (2012)

the disaster in more than half of those who owned less than 5 ha of land and had wanted to maintain the current scale of their operations before the disaster.

We also analyzed the impact of damage to farmlands and farming machinery on inclination to farm. The results showed that, the greater the damage, the greater the impact both factors tended to have on inclination to farm. Furthermore, the difference in the correlation coefficients indicates that the extent of the damage to farming machinery had a bigger impact on the decline in inclination to farm than the damage to paddy fields typically caused by seawater flooding (Table 5.1). Although public aid could be expected for rehabilitating farmlands, farming machinery was as a rule bought and owned on an individual basis, and levels of damage varied. As a result, farmers whose machinery was damaged would need to replace all the lost machinery themselves, which would require substantial expenditure exceeding 10 million yen. And, if that was the case, they could expect no public funding. Meanwhile, a slump in the price of rice during the past few years is also thought to have accelerated the decline in inclination to farm.

However, there were still some large-scale farmers who suffered little damage. Such farmers continue to be inclined toward expanding their scale of operations, and this survey suggests that these bigger players might be able to take over the farmland of those who want to reduce their operations or leave the industry entirely.

\subsection{Activities of Regional Agricultural Recovery Associations: Characteristics and Evaluation}

\subsubsection{Scheme to Subsidize Resumption of Farming Activities and Regional Agricultural Recovery Associations}

The Ministry of Agriculture, Forestry and Fisheries created a scheme to help farmers start operating their farms again by paying a redevelopment subsidy of 35,000 yen for every 10 ares of paddy. The aim was to expedite resumption of farming and 
restore agriculture in the disaster zones. Under the scheme, the subsidy is paid via regional agricultural recovery associations to farmers affected by the disasters when they work together on activities to restart farming operations, such as straightforward garbage and debris removal, repair of ridges between rice paddies, repair of water conduits, and removal of salt.

\subsubsection{Survey on Recovery Association Activities in Soma City and Issues Faced}

We conducted an oral survey of 16 recovery associations in the city of Soma from November 12 to 21,2011 . The purpose was to establish what activities they were engaged in and the issues they faced, as well as to investigate what direction future recovery activities should take (Table 5.2).

Table 5.2 Overview of regional agricultural recovery associations in Soma

\begin{tabular}{l|l|l|r}
\hline Number & Individual recovery association & $\begin{array}{l}\text { Number of constituents } \\
\text { (persons) }\end{array}$ & Area (a) \\
\hline 01 & Tsukanobe & 46 & $1,948.01$ \\
\hline 02 & Ishigami & 75 & $2,654.68$ \\
\hline 03 & Niida & 101 & $2,842.37$ \\
\hline 04 & Haragama & 146 & $2,796.03$ \\
\hline 05 & Wada & 105 & $4,798.04$ \\
\hline 06 & Nakago & 74 & $1,518.99$ \\
\hline 07 & Motowarou & 46 & $1,685.19$ \\
\hline 08 & Minamiiibuchi & 49 & $2,606.89$ \\
\hline 09 & Iwanoko & 153 & $9,923.76$ \\
\hline 10 & Niida & 123 & $13,629.58$ \\
\hline 11 & Hodota & 94 & $5,952.17$ \\
\hline 12 & Nikkeshi & 71 & $4,630.95$ \\
\hline 13 & Kashiwazaki & 148 & $10,278.05$ \\
\hline 14 & Isobe & 295 & $19,067.48$ \\
\hline 15 & Koisobe & 70 & $4,798.33$ \\
\hline 16 & Yunukiyachida & 20 & $1,238.1$ \\
\hline 17 & Yunukitatemae & 17 & $1,156.57$ \\
\hline 18 & Fukushimaken-hamadori & 40 & $12,178.77$ \\
\hline & Farmers' joint association & & \\
\hline & & &
\end{tabular}

Source: Batdelger et al. (2012) 


\subsubsection{Recovery Associations and Their Activities According to Level of Tsunami Damage}

\subsubsection{Classifying Tsunami Damage Level}

Based on the research outcomes to date, we classified levels of tsunami damage from three perspectives - damage to farmland, damage to irrigation facilities such as water supply and drainage channels, and damage to farming machinery owned by the association members (Table 5.3).

Damage to farmland was classified according to how long the farmland had been flooded, the amount of building debris, the amount of debris from windbreaker forests, and accumulation of tsunami sediment, with two or three possible levels of damage defined for each of these factors.

Table 5.4 summarizes damage levels as assessed by the recovery associations according to the foregoing classifications. The numbers $01-17$ represent the individual recovery associations. As the table shows, the reported levels of tsunami damage to farmlands, irrigation facilities, and farming machinery were diverse.

Next, two clusters were extracted using cluster analysis to classify the damage levels objectively (Fig. 5.1).

Table 5.3 Classification of damage sustained by regional agricultural recovery associations in Soma

\begin{tabular}{l|l|l|l|l}
\hline \multicolumn{2}{l|}{ Classification of damage } & A & B & C \\
\hline $\begin{array}{l}\text { Damage to } \\
\text { farmland }\end{array}$ & $\begin{array}{l}\text { How long the } \\
\text { farmland had been } \\
\text { flooded }\end{array}$ & $\begin{array}{l}\text { Less than } \\
\text { 3 weeks (short } \\
\text { period) }\end{array}$ & - & $\begin{array}{l}\text { More than 3 weeks } \\
\text { (long period) }\end{array}$ \\
\cline { 2 - 5 } & $\begin{array}{l}\text { Amount of } \\
\text { building debris }\end{array}$ & Nothing & $\begin{array}{l}\text { Accumulation on } \\
\text { some farmland }\end{array}$ & $\begin{array}{l}\text { Far-reaching and } \\
\text { extensive } \\
\text { accumulation }\end{array}$ \\
\cline { 2 - 5 } & $\begin{array}{l}\text { Debris from } \\
\text { windbreaker } \\
\text { forests }\end{array}$ & Nothing & - & $\begin{array}{l}\text { A lot of } \\
\text { accumulation }\end{array}$ \\
\cline { 2 - 5 } $\begin{array}{l}\text { Accumulation of } \\
\text { tsunami sediment }\end{array}$ & $\begin{array}{l}\text { Partially thin } \\
\text { accumulation }\end{array}$ & $\begin{array}{l}\text { Partially thick } \\
\text { accumulation }\end{array}$ & $\begin{array}{l}\text { Far-reaching } \\
\text { extensive and thick } \\
\text { accumulation }\end{array}$ \\
\hline Damage to irrigation facilities & $\begin{array}{l}\text { Functional } \\
\text { maintenance }\end{array}$ & $\begin{array}{l}\text { Slight and } \\
\text { restored damage } \\
\text { (only sediment } \\
\text { accumulation) }\end{array}$ & $\begin{array}{l}\text { Damage with } \\
\text { difficult restoration }\end{array}$ \\
\hline
\end{tabular}

Source: Batdelger et al. (2012)

Notes: "A" in front shows damage smallness, as for "B"; "C" shows the damage situation in order of damage size among damage, and writers classified from the result of the interview Moreover, the part currently described by "-" was classified according to two steps of damage situations of the size of damage 
Table 5.4 Damage to recovery associations' farmlands and irrigation facilities and to members' farming machinery

\begin{tabular}{|c|c|c|c|c|c|c|c|c|c|c|}
\hline \multicolumn{2}{|c|}{ Association no. } & \multirow{2}{*}{$\begin{array}{l}01 \\
\mathrm{~A}\end{array}$} & \multirow{2}{*}{$\begin{array}{l}02 \\
A\end{array}$} & \multirow{2}{*}{\begin{tabular}{|l|}
03 \\
A \\
\end{tabular}} & \multirow{2}{*}{$\begin{array}{l}04 \\
\text { Unestablished } \\
\text { association }\end{array}$} & \multirow{2}{*}{\begin{tabular}{|l|}
05 \\
A
\end{tabular}} & \multirow{2}{*}{\begin{tabular}{|l|}
06 \\
$\mathrm{C}$ \\
\end{tabular}} & \multirow{2}{*}{\begin{tabular}{|l|}
07 \\
A
\end{tabular}} & \multirow{2}{*}{$\begin{array}{l}08 \\
\mathrm{~A}\end{array}$} & \multirow{2}{*}{$\begin{array}{l}09 \\
\mathrm{C}\end{array}$} \\
\hline $\begin{array}{l}\text { Damage to } \\
\text { farmland }\end{array}$ & $\begin{array}{l}\text { How long the } \\
\text { farmland had been } \\
\text { flooded }\end{array}$ & & & & & & & & & \\
\hline & $\begin{array}{l}\text { Amount of building } \\
\text { debris }\end{array}$ & A & A & A & & B & A & A & A & A \\
\hline & $\begin{array}{l}\text { Debris from } \\
\text { windbreaker forests }\end{array}$ & A & A & A & & $\mathrm{C}$ & $\mathrm{C}$ & A & A & $\mathrm{C}$ \\
\hline & $\begin{array}{l}\text { Accumulation of } \\
\text { tsunami sediment }\end{array}$ & A & A & B & & B & $\mathrm{C}$ & B & $\mathrm{C}$ & $\mathrm{C}$ \\
\hline \multicolumn{2}{|c|}{ Damage to irrigation facilities } & B & A & B & & B & $\mathrm{C}$ & A & A & $\mathrm{C}$ \\
\hline \multicolumn{2}{|c|}{ Damage to farming machinery } & A & A & A & & B & A & A & A & $\mathrm{B}$ \\
\hline \multicolumn{2}{|c|}{ Association no. } & 10 & 11 & 12 & 13 & 14 & 15 & 16 & 17 & 18 \\
\hline \multirow[t]{4}{*}{$\begin{array}{l}\text { Damage to } \\
\text { farmland }\end{array}$} & $\begin{array}{l}\text { How long the } \\
\text { farmland had been } \\
\text { flooded }\end{array}$ & $\mathrm{C}$ & A & C & $\mathrm{C}$ & $\mathrm{C}$ & $\mathrm{C}$ & A & A & \multirow[t]{6}{*}{$\begin{array}{l}\text { Uninvestigated } \\
\text { association }\end{array}$} \\
\hline & $\begin{array}{l}\text { Amount of building } \\
\text { debris }\end{array}$ & A & A & $\mathrm{C}$ & $\mathrm{C}$ & $\mathrm{C}$ & $\mathrm{C}$ & A & B & \\
\hline & $\begin{array}{l}\text { Debris from } \\
\text { windbreaker forests }\end{array}$ & $\mathrm{C}$ & A & C & $\mathrm{C}$ & $\mathrm{C}$ & $\mathrm{C}$ & $\mathrm{C}$ & A & \\
\hline & $\begin{array}{l}\text { Accumulation of } \\
\text { tsunami sediment }\end{array}$ & $\mathrm{C}$ & B & C & $\mathrm{C}$ & $\mathrm{C}$ & $\mathrm{C}$ & B & B & \\
\hline \multicolumn{2}{|c|}{ Damage to irrigation facilities } & $\mathrm{C}$ & B & $\mathrm{B}$ & $\mathrm{C}$ & $\mathrm{C}$ & $\mathrm{C}$ & $\mathrm{B}$ & A & \\
\hline \multicolumn{2}{|c|}{ Damage to farming machinery } & $\mathrm{C}$ & A & A & A & $\mathrm{C}$ & $\mathrm{C}$ & A & A & \\
\hline
\end{tabular}

Source: Batdelger et al. (2012)

Notes: (1) "A" in front shows damage smallness, as for "B"; "C" shows the damage situation in order of damage size among damage, and writers classified from the result of the interview

(2) Association " 04 " was not established; Association " 08 " was not investigated

\subsubsection{Features of Recovery Association Activities by Tsunami Damage Level}

Table 5.5 summarizes features of the main activities carried out by the recovery associations according to the classification obtained from cluster analysis. As shown, the recovery associations that had suffered severe damage generally had joint operational structures, with priority given to cultivators when paying subsidies.

Specifically, the farmlands of associations in Cluster 1 Group I $(12,13,14,15)$ contained large volumes of post-tsunami glass and concrete fragments mixed into the soil, and radical measures to remove these were required. However, it was difficult for the associations to implement such measures on their own. At the time of the survey, therefore, only temporary fixes such as mowing of the ridges had been implemented and real agricultural reconstruction had not started. The Tokyo University of Agriculture subsequently addressed this issue by enlisting the help of a farming machinery manufacturer to conduct a demonstration on how to remove 


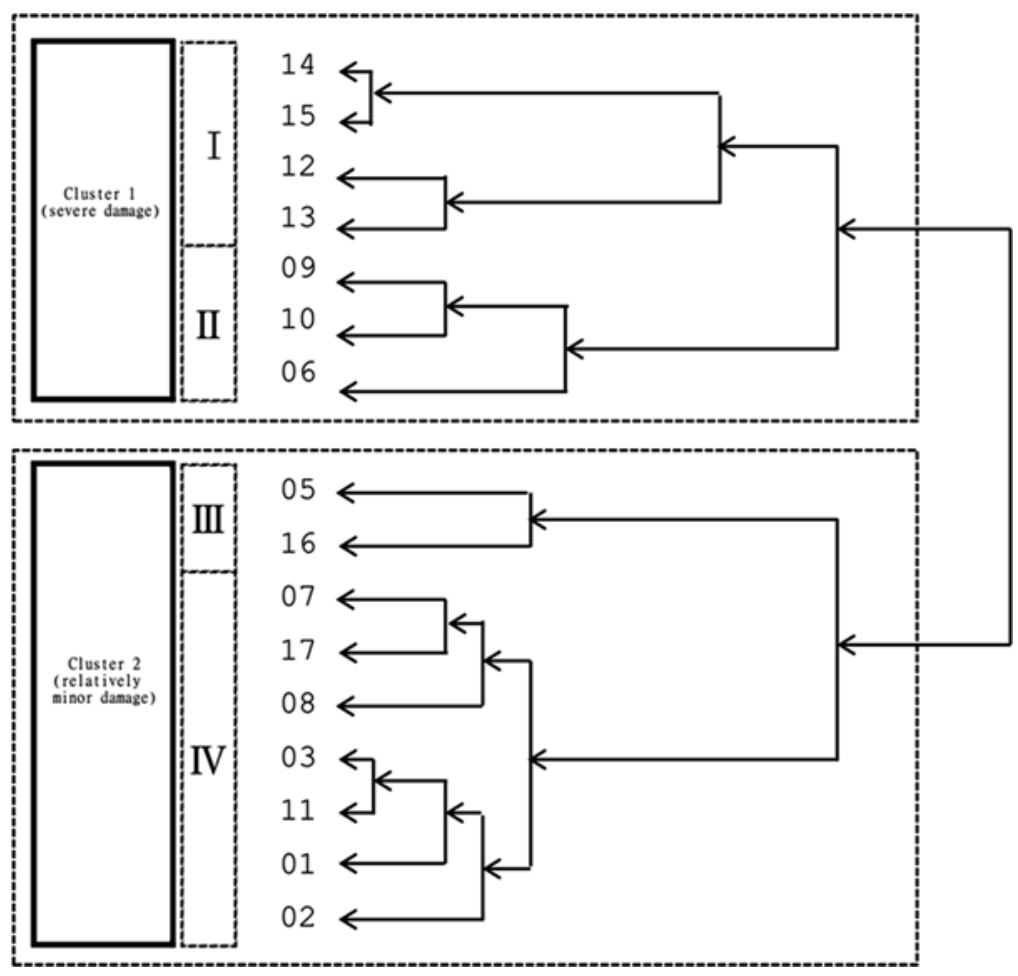

Fig. 5.1 Cluster analysis-based classification of regional agricultural recovery associations in Soma (From Batdelger et al. 2012)

fine debris buried in the soil. As a result, debris removal has now become one of the activities carried out by the associations themselves.

For associations classified under Cluster 1 Group II, whose farmlands contained no building debris $(09,10,06)$, there was believed to be little need to remove topsoil. Moreover, we tried removing salt from some of Association 09's farmlands and found that the lack of glass and concrete fragments reduced the time and cost required for reconstruction significantly. In other words, it can be said that the subsidies granted under the government's scheme to help farmers resume farming are being used effectively for agricultural recovery and repair work.

Among recovery associations in areas that suffered relatively minor damage, we found that most of the repair work was undertaken at an individual level. We also managed to verify that wet tillage-based salt removal had already been carried out between three and five times by the associations or their members. In addition, most of the associations classified under Cluster 2 had undertaken repair work with the specific aim of planting rice by the following year. We found, therefore, that the subsidies were being used effectively for repair work to secure the incomes of the farmers affected by the disasters. 


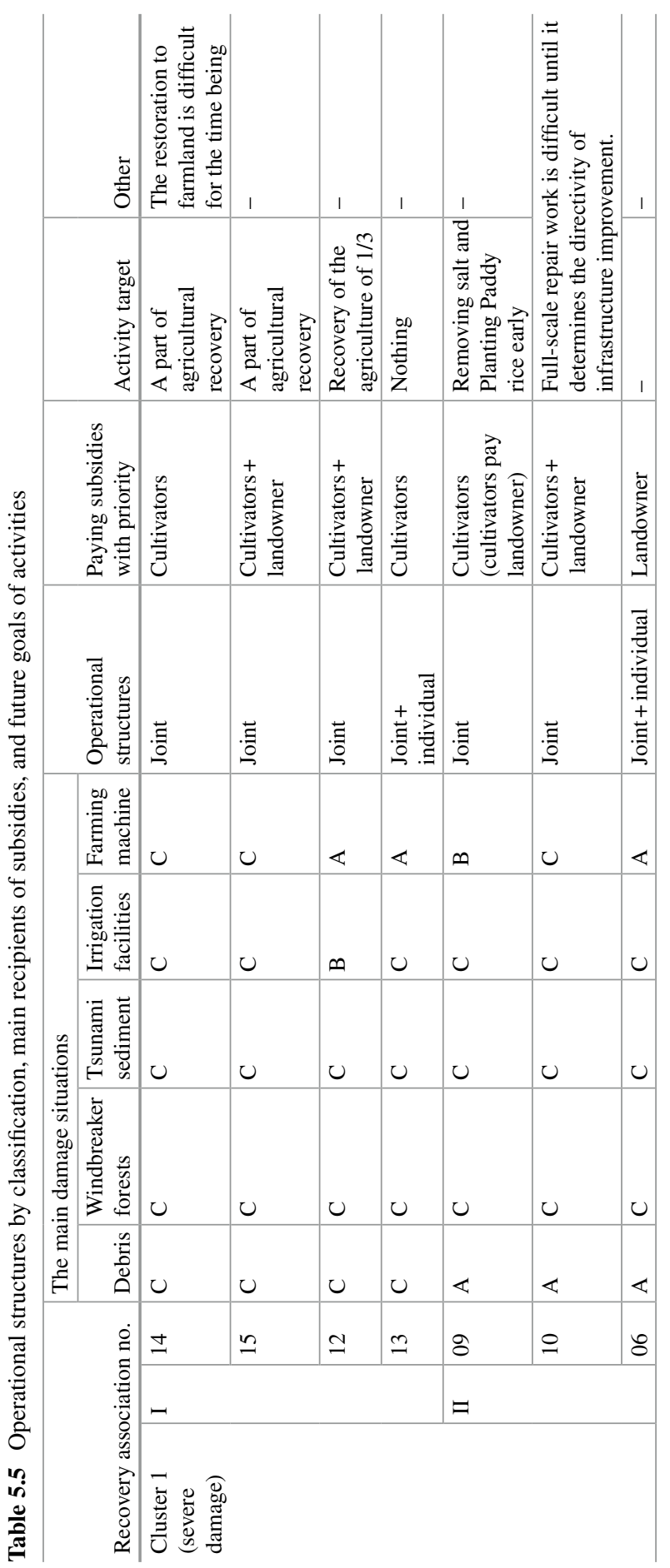




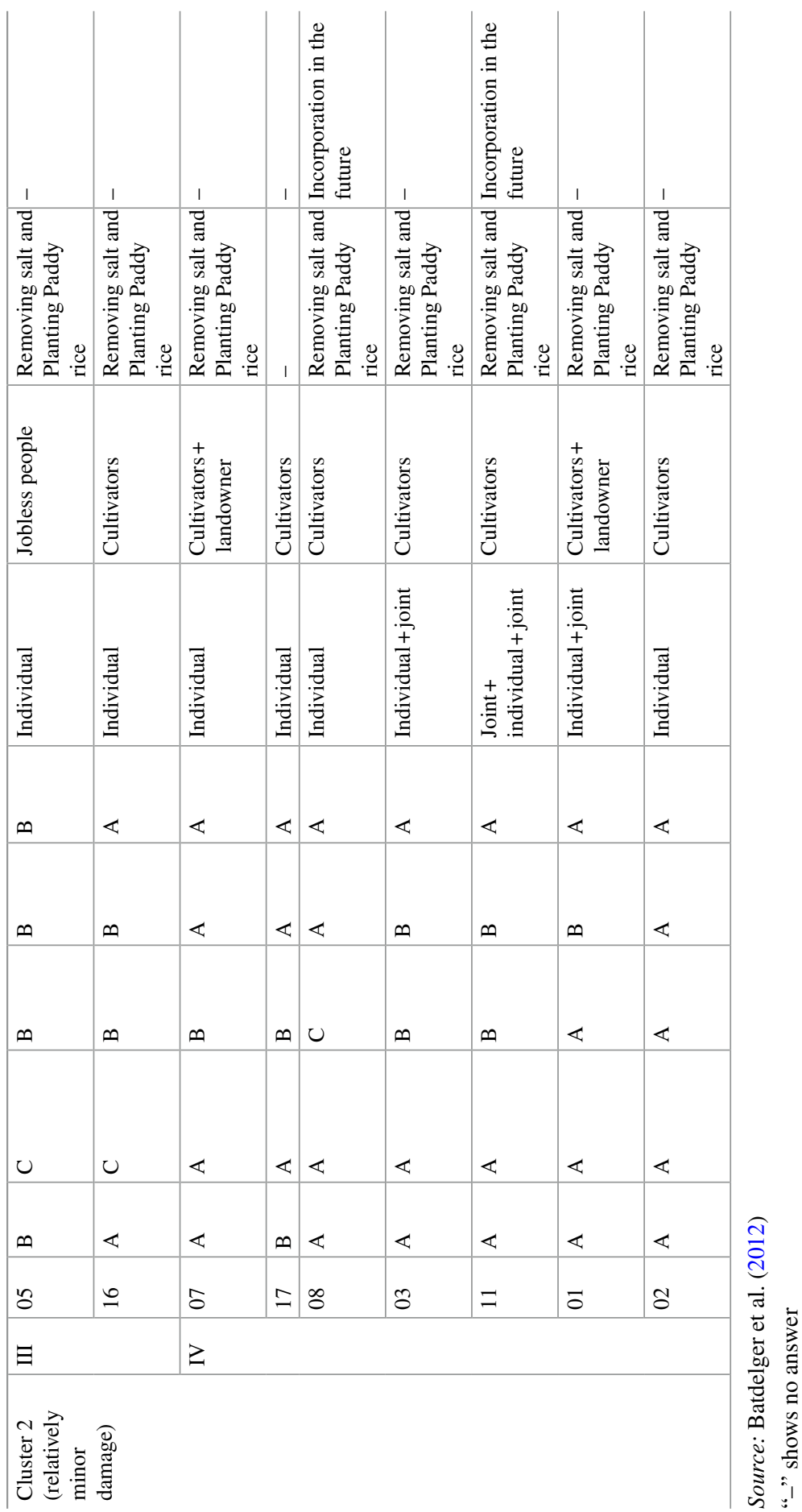




\subsubsection{The Recovery Assistance Project: Challenges and Optimal Implementation Method}

The key consideration in implementing a project to accelerate recovery is above all to deploy measures tailored to the specific level of damage. As seen in the past, uniform recovery assistance projects that ignore the diversity of the damage are not necessarily very effective. In addition, the establishment of recovery associations to overcome the harsh conditions imposed by these particular disasters belies the fact that farming via community-based organizations has not traditionally been the norm in Soma. Looking ahead, therefore, recovery association activities could be further developed to create new entities to help take responsibility for agricultural reconstruction. (Batdelger et al. 2012)

\subsection{Impetus for the Formation of Agricultural Corporations and Process of Incorporation}

\subsubsection{Background of Agricultural Corporations in Soma}

From the early stages after the disasters, the Soma City authority considered a policy of developing agricultural corporations. In February 2012, a restoration project focusing on soybean production in Soma was established with a 300 million yen grant from the Yamato Welfare Foundation. The aim of the project was to support the establishment of new agricultural corporations to produce, process, and sell soybeans in communities that were affected by the tsunami, such as Minami Iibuchi, Iwanoko, Niida, and Hodota. Specifically, the project provides farming machinery including large tractors of the 100-hp class required for soybean production.

\subsubsection{Features of the Three Agricultural Corporations}

Following is a brief overview of the three soybean corporations established in the city of Soma and the process leading up to their incorporation (see Table 5.6).

\subsubsection{Iitoyo Farm LLC}

Farmers in the litoyo area farmed about 2 ha on average on a self-sufficient basis and farmwork was almost never outsourced. The Soma City authority first suggested creating an agricultural corporation to the farmers in February 2012, and the company was incorporated within a very short period, at the beginning of April the same year. 
Table 5.6 Soybean corporations established in Soma after the disasters

\begin{tabular}{|c|c|c|c|}
\hline Corporation name & Iitoyo Farm LLC & Iwanoko Farm LLC & Agrifood Iibuchi LLC \\
\hline Establishment area & Niida, Hodota & Iwanoko & Minamiiibuchi \\
\hline Date of foundation & April 2, 2012 & May 18, 2012 & May 31, 2012 \\
\hline $\begin{array}{l}\text { Disaster farmland } \\
\text { area }\end{array}$ & $\begin{array}{l}196 \text { ha (Niida } \\
136 \text { ha + Hodota } \\
60 \text { ha) }\end{array}$ & 99 ha & 26 ha \\
\hline $\begin{array}{l}\text { Recovery } \\
\text { association number }\end{array}$ & $\begin{array}{l}217 \text { houses (Niida } \\
123 \text { houses + Hodota } \\
94 \text { houses) }\end{array}$ & 153 houses & 49 houses \\
\hline Total farmland area & 240 ha & 140 ha & 40 ha \\
\hline Directors & $\begin{array}{l}\text { Niida } 3 \\
\text { persons + Hodota } 1 \\
\text { persons }\end{array}$ & 4 persons & 6 persons \\
\hline Directors' feature & $\begin{array}{l}\text { A full-time farmer } \\
\text { is a center. }\end{array}$ & $\begin{array}{l}\text { Part-time farm } \\
\text { households, such as } \\
\text { dried-seaweed } \\
\text { aquaculture, are centers. }\end{array}$ & $\begin{array}{l}\text { A horticultural farmer } \\
\text { and a part-time farm } \\
\text { household are centers. }\end{array}$ \\
\hline
\end{tabular}

One key feature of Iitoyo Farm is the size of the farming area that serves as its production base. In addition to the 190 ha that was damaged, there was another 50 ha that was undamaged, making a total of 240 ha. In addition, the directors of Iitoyo Farm are different from those of other corporations in that all four are fulltime farmers. They cultivate 18 ha, 8 ha, 8 ha, and 2 ha, respectively, the first three directors clearly being large-scale farmers within the area. In addition, the director who cultivates 2 ha has long years of experience in housing sales, and could therefore play a key role in sales as the business expands in future.

As the board of litoyo Farm is composed of full-time farmers, it is not simply a community farm that aims to maintain its farmlands, but a corporation that aims to develop and expand its business continually in future. To ensure this continuity, the corporation needs to pay salaries on a par with other industries and secure talented staff who can be entrusted with the running of the business in future. The directors therefore urgently need to put the management of their business on a firm footing and raise revenue. If they continue to focus exclusively on crop production, as in the past, not only will work dry up in winter, but added value will also not increase. Therefore, the directors share the belief that a professional approach to agricultural production that includes processing and sales is the way forward.

\subsubsection{Iwanoko Farm LLC}

The Iwanoko district is situated in the northern part of the central reclaimed land next to Matsukawaura Lagoon. Consequently, many of the farmers cultivate edible seaweed in addition to farming. Currently, seaweed cultivation is the main business and there is no one who specializes in farming alone. The total farming area in the district measures 140 ha, with 100 ha producing rice and the remaining 40 ha 
producing soybeans. Before the disasters, a voluntary association called Iwanoko Farm undertook crop rotation-based production under a community farming structure. Soybean production amounted to a harvest of about $200 \mathrm{~kg} / 10$ ares. The local agricultural cooperative shipped the produce, which was of high quality and sold well.

The farm's managers currently have no plans to expand into a new business structure that can take on large investments and risks.

\subsubsection{Agrifood Iibuchi LLC}

The Minami Iibuchi district is located on the upper reaches of the reclaimed land. As the land under cultivation straddles the Route 6 bypass from east to west, the adverse effects of the tsunami were relatively minor compared to the damage to land cultivated by the other two corporations. The area between the bypass and the town, in particular, escaped almost unscathed. Only three or four farmers suffered damage to their machinery and only one person (one of the directors) left farming because of the tsunami. The total area of farmland in the district is small at 40 ha, with no farmers involved in full-time rice cultivation.

The farmers in this corporation's region are aging, and the board consists of only older and part-time farmers. They therefore need to secure successors to take over the business and to review the structure of the community's agriculture that has so far been composed of mainly part-time farmers.

\subsection{Local Farmers' Expectations and Demands of the Agricultural Corporations}

\subsubsection{Survey Background and Method for Iitoyo Farm}

Iitoyo Farm was established in April 2012, and by May it needed a specific business plan. That was the point at which the farm's managers realized that to prepare for full-scale resumption of farming the following year, they needed to understand (a) the extent to which they could expect the corporation to consolidate farmlands in the Iitoyo area (to indicate the corporation's likely scale of operations), (b) the potential for making the farmers more aware of the corporation and securing their collaboration, and (c) any specific requests the region's farmers may have.

From July 18 to August 8, 2012, we therefore conducted a questionnaire survey of farmers in the area where the Iitoyo Farm had been established. The number of questionnaires sent out was 208 , and 90 replies were received, resulting in an effective response rate of $42.8 \%$. 


\subsubsection{Farming Before and After the Disasters and Changes in the Farmers' Inclination to Farm}

Survey questions about how the paddies were cultivated and managed the year before the disaster revealed that the area of leased paddy was 80 ha and the area of paddy where all work was outsourced was 29 ha. Combining these two, the total leased or outsourced paddy area in the Iitoyo district was at least 110 ha before the disasters struck. Taking into account the $42.8 \%$ effective response rate and the overall decline in farmers' inclination to continue farming their own land after the disasters (to be described later), it is possible that the amount of farmland either leased or outsourced could far outstrip that 110 ha in future.

We asked the farmers whether they were interested in entrusting their farmland to their community's agricultural corporation, the Iitoyo Farm. In response, $54 \%$ replied that they would not mind doing so, and $10 \%$ replied that it would depend on the services offered. Depending on how the corporation develops it services, therefore, this $10 \%$ will probably also entrust their land to the corporation. Only $17 \%$ clearly stated that they were against the idea. However, it is also likely that farmers who did not reply or were still undecided will find it difficult to cultivate their land themselves. As a consequence, consolidation of farmlands under the corporation is expected to increase significantly in future.

\subsubsection{Management of the Iitoyo Farm by the Region's Farmers}

The directors of Iitoyo Farm are four full-time farmers. Because they are all relatively young, ranging in age from 48 to 57 , they are reasonably well able to cope with expansion of the area under cultivation. However, before the disaster, the two communities of Niida and Hodota that comprise the Iitoyo area already contained 110 ha of leased or outsourced land, and bearing in mind the number of farmers who are considering scaling down or leaving the industry as a result of the disaster, a total of 190 ha of damaged land may become available for leasing or outsourcing. If we exclude the $17 \%$ of farmers who did not wish to entrust their farmland to the corporation, then $83 \%$ of 190 ha, or approximately 160 ha of farmland, may be consolidated by the corporation. Furthermore, if the 50 ha of undamaged farmland were added to make the total available land 240 ha, then the area that may be consolidated would rise to 200 ha. With such a scale of operations, it would not be possible for the four directors to cultivate the land alone.

This being the case, collaboration among the farmers of the region is considered necessary. We therefore asked the farmers about how they intended to participate in the newly established agricultural corporation (Table 5.7).

These results suggest that there is a greater likelihood of consolidating a large farming area if it is assumed that local farmers will play a role within the corporation. 
Table 5.7 Intended participation in the agricultural corporation

\begin{tabular}{|c|c|c|c|}
\hline & $\begin{array}{l}\text { Person } \\
\text { himself/ } \\
\text { herself }\end{array}$ & $\begin{array}{l}\text { Parents, } \\
\text { Spouse }\end{array}$ & Children \\
\hline [Full-time] It is due to participation as a director. & 5 & - & 0 \\
\hline [Full-time] It is easy to be based on operator work. & 6 & 2 & 2 \\
\hline $\begin{array}{l}\text { [Full-time] It is easy to be simple agricultural work } \\
\text { and auxiliary work. }\end{array}$ & 7 & 4 & 0 \\
\hline $\begin{array}{l}\text { [Full-time] It is employment hope at a future director } \\
\text { candidate. }\end{array}$ & 2 & 1 & 0 \\
\hline [Temporary] It is easy to be operator work. & 7 & 0 & 1 \\
\hline $\begin{array}{l}\text { [Temporary] It is easy to be simple agricultural work } \\
\text { and auxiliary work. }\end{array}$ & 10 & 10 & 1 \\
\hline $\begin{array}{l}\text { [Temporary] It is easy to be grass and water } \\
\text { management work. }\end{array}$ & 5 & 5 & 1 \\
\hline Not wish/Unknown/No answer & 47 & 67 & 84 \\
\hline Sum total & 89 & 89 & 89 \\
\hline
\end{tabular}

Source: Cited from Shibuya et al. (2013)

\subsubsection{Agricultural Corporations in the Disaster Zones: Potential and Expectations}

Large-scale agricultural corporations focusing on rice cultivation can be seen across the country, but none of them grew big overnight. Instead, they expanded to their current scale gradually as they accumulated experience and knowledge. In contrast, the agricultural corporations established in the disaster zones face unprecedented challenges as large areas exceeding 100 ha have to be farmed even during the 2- to 3 -year period when the farmland and irrigation infrastructure are being restored. For this reason, business management capabilities need to be enhanced.

The success of the agricultural corporations established in the city of Soma is expected to serve as a model not only for the reconstruction of rice paddies affected by the Great East Japan Earthquake but also for resolving issues faced by the rice cultivation industry in Japan as a whole as a consequence of its aging population.

\subsection{The Strawberry Farm Corporation: Characteristics of Activities and Future Strategy}

\subsubsection{Overview of the Wada District's Strawberry-Producing Area}

The Wada district of the city of Soma lies to the west of Matsukawaura Lagoon and is located relatively close to the tourism and hotel district centered on Matsukawaura. Strawberry production started a long time ago in this area, and the Wada strawberry 
Table 5.8 Overview of Wada strawberry farm

\begin{tabular}{l|l}
\hline Corporation name & Limited liability company: "Wada strawberry Farm" \\
\hline Date of foundation & May 11, 2012 \\
\hline Capital & 1 million yen \\
\hline Corporate directors & 7 persons \\
\hline Institution scale & $\begin{array}{l}\text { Cultivation house: Two houses of } 650 \text { tsubos, one house of } 450 \text { tsubos } \\
\text { (all are an elevated culturing apparatus) }\end{array}$ \\
\cline { 2 - 2 } & $\begin{array}{l}\text { Seedling raising house: Four vinyl houses of 30 meters, four vinyl } \\
\text { houses of 40 meters }\end{array}$ \\
\hline Business name & Recovery grant \\
\hline Amount of money & 240 million yen (the part in the Heisei 24 fiscal year) \\
\hline
\end{tabular}

association was established in 1988. The members of the association each managed their own operations, and the number of members before the disaster was only 13 in this small-scale strawberry-producing area.

\subsubsection{Events Leading to the Establishment of the Corporation}

Among the 13 members, 7 were forced to cease operating as a result of the tsunami caused by the Great East Japan Earthquake, and only 6 sustained no damage to their greenhouses. As revenue was derived from strawberry picking and direct sales, business was dependent on visitors coming. But if the greenhouse area available was reduced, the district would be unable to fully cater to its visitors, losing its appeal as a strawberry-producing area. As a consequence, any potential reduction in the number of strawberry farmers was a problem that affected the whole association. The farmers therefore consulted the Soma City authority and sought national recovery aid to incorporate a limited liability company (Table 5.8).

\subsubsection{Overview of Events Leading to Construction of the Greenhouses and Their Management}

The greenhouses in the Wada strawberry farm were all built using a recovery grant (Fig.5.2). Following discussion, the members decided that, instead of owning the greenhouses as individual assets, they would build and operate them as assets of the limited liability company. Behind this decision was the issue of succession. If a sturdy greenhouse is built, it can be operated continuously for several decades. However, most of the members did not have any confirmed successors and it was possible that, despite having greenhouses, there could be no one to take them over. They therefore decided that building and operating the greenhouses under the auspices of the association would lead to their continued and effective use. 


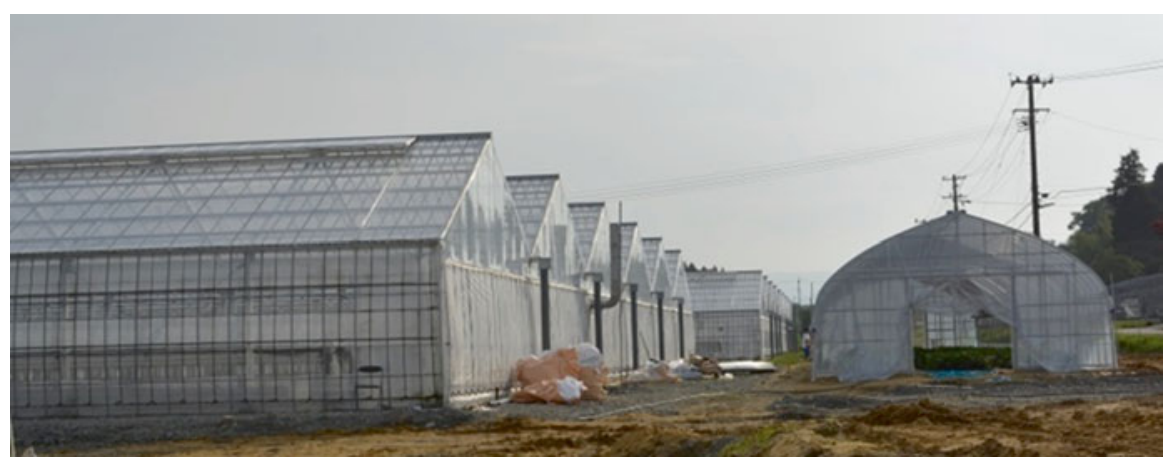

Fig. 5.2 Linked strawberry greenhouses (left) and seedling greenhouse (right) constructed using a recovery grant

\subsubsection{Discussion of Incorporation Initiative in the Wada District}

Despite administering a small area with only 13 farming households, the Wada strawberry association has managed to develop during its 25 years. Using a national recovery grant, the association's members set themselves up to repair their production facilities. Considering the future need for farmers and overall management of the business, they also took the opportunity to switch from an individual to a corporate management structure.

One common worry faced by farmers in areas such as this that have been producing agricultural products for 25 years, or almost a generation, is the issue of succession. In the Wada district, the crisis brought on by the disasters provided the impetus for the farmers to discover incorporation as a means to resolve this perennial issue. Indeed, this example of independent operators joining together merits attention as a means to solve the issue of succession among farmers, whose businesses are said to be the most difficult of all businesses to consolidate. The farmers' choice on this occasion reflected the fact that it was easy to reach a consensus within the Wada district, a small area with only 13 farming households. Whether this decision will turn out to be a blessing depends largely on the future efforts of the members of the limited liability company. 


\subsection{Recovery Based on Agricultural Corporations: Future Direction and Issues}

\subsubsection{Agriculture in Tsunami-Stricken Areas of Soma and Its Features}

Within the city of Soma, the areas affected by the disasters were mainly paddy fields on reclaimed land that had continued to enjoy favorable conditions since the Edo Period (1603-1868). The farmers' landholdings were larger than was the norm in Japan, averaging about 2 ha in Niida district, for example. Even now that many farmers farm only part-time, self-sufficient, individual management is usual, and at the time of the disasters community farming and agricultural corporations were almost unknown.

However, a long-term slump in the price of rice meant that conditions were getting tougher year after year. Amid such a harsh business environment, agriculture had become a way to maintain the family property rather than a means to acquire income, and as such it was inevitably sustained mainly by senior citizens. For many years before the disasters it had been the norm for potential successors among the young to find work outside of agriculture, and some farmers had actually started leaving the industry for lack of a successor. It can therefore be said that, even before the disasters, agriculture in Soma was nearing crisis point in terms of both revenue and people to take over. This problem is not limited to the city of Soma, but is common to all agricultural regions throughout Japan.

\subsubsection{Recovery Based on Incorporation: Future Direction and Strategy}

Thus, paddy field rice cultivation in Soma was barely surviving. Then the farmlands serving as a common production base for the region were severely damaged as a result of the tsunami, along with individual assets such as farming machinery. As far as self-sufficient rice cultivation was concerned, the damage to machinery in particular became a key factor in farmers deciding to give up farming.

Naturally, the city needs to avoid a situation whereby the national budget is used to restore farmland, facilities, and farming machinery to their original state as part of the disaster recovery effort, only for these assets to fall into disuse several years later. However, simply returning to the previous self-sufficient model risks wasting the recovery budget because of the continual crisis brought about by farmers retiring. 
After the disasters, the farmers' attitudes to farming changed because of such concerns about succession and the damage their farms and machinery had sustained. The city authority reacted to these changes in attitude by promoting incorporation both inside and outside the city from the early stages of recovery planning. This approach set the scene for the city authority, which applied for the Yamato Welfare Foundation's reconstruction and recovery fund, to stipulate incorporation as a condition when farmers applied to lease farming machinery. However, the city authority did more than simply lay down conditions; it deserves mention for also assisting with paperwork, providing advice, and building consensus in a timely manner during the incorporation process. In the Wada district, the city also advanced the cause of incorporation by building the latest strawberry greenhouses using elevated hydroponic cultivation with the help of a government recovery grant. Incorporation offers huge potential for improving a farming business economically in terms of operating efficiency and profitability because of the greater economy of scale. It also offers huge potential for improvement from a human resources point of view by providing a means of ensuring succession.

Management resources can generally be said to consist of people, equipment, and money. Equipment (large farming machinery and the latest greenhouses) acquired through recovery projects can serve as a means of bringing in people (successors) and money (profitability) to furnish all three resources. With these three elements in place, the city of Soma can be said to have taken a strategic approach to establishing the basic conditions for its agriculture to grow over the long term. The strategy aims to resolve local agricultural management issues by using equipment as the means to induce people- and money-related changes. Besides serving as a model for other regions recovering from the disasters, such a strategy can be said to represent a breakthrough for Japan's agricultural industry in general, which is facing the same issues.

\subsubsection{Agricultural Recovery Based on Incorporation: Issues}

The crisis caused by the unprecedented tsunami damage can be used as a catalyst to restructure the agricultural industry, and incorporation can be described as key to that strategy. The strategy is just getting under way in the city of Soma, but there are issues involved. In terms of the three management resources, simply building an environment where people (successors) can be found is not sufficient. Perhaps the biggest issue is whether Soma's existing farmers within the new corporations can make use of the equipment (large farming machinery and the latest greenhouses) that the corporations and the recovery process have made available to them. Only by using that equipment to realize greater economy of scale, systematization, and efficiency can they achieve the desired management outcome of generating money (increased profits). 
Farmers therefore need to discard the mindset cultivated during the era of selfsufficiency and acquire the new mindset and management skills of corporate managers.

Open Access This chapter is distributed under the terms of the Creative Commons Attribution Noncommercial License, which permits any noncommercial use, distribution, and reproduction in any medium, provided the original author(s) and source are credited.

\section{References}

Batdelger N, Yamada T, Suzumura G, Shibuya Y, Lurhathaiopath P, Monma T (2012) Actual situation and evaluation of reconstruction union activities in tsunami-damaged area. J Rural Econ 2012(Special Issue):192-198 (in Japanese)

Shibuya Y, Yamada T, Batdelger N, Lurhathaiopath P, Niitsuma T, Usuki M, Monma T (2012) A study of intention to keep on farming and its factors on the farmers suffered from the Great East Japan Earthquake. Jpn J Farm Manag 50(2):66-71 (in Japanese)

Shibuya Y, Yamada T, Monma T (2013) Trends and subjects on incorporation of agriculture at tsunami stricken area: a case study in Soma, Fukushima. Jpn J Farm Manag 50(4):87-92 (in Japanese) 